\title{
Digital Archives Management and Permanent Storage of Documents
}

\author{
FIKRIE BERISHA, PH.D. \\ Master on Archivism, Worker in the State Agency of Kosovo archives, \\ e-mail: fikrieberisha@gmail.com
}

Digital Archives Management and Permanent Storage of Documents

\section{ABSTRACT}

Modern digital archives are modern archives which in big computer devices (servers), preserve archived original document overlooking the moment is produced. Archives in Kosovo assessment of archival documents make in two directions. First; selection of classical documents (on paper) with the value to be transformed into digital documents, and second; selection of contemporary documents produced by institutions of computer and internet era. Management of these digital documents requires procedures and professional standards for its storage and processing by the archive, in order to be ready to serve researchers and interested parties. Access to digital documents should be fast, simple procedures, providing documentation from the penetration of 'hackers' and people badly intention. To fulfil its mission digital document should ensure and complement the appearance of the original document. Since the user does not have the option of intervention and change in the document. Should work in protect emblem, which protects the entire area of the document in the form of molten seal, which also shows the ownership of certain archive. Safety documentation and document base by external users will be able to organize, deposit and stored at three levels: Server (1) be stored (saved) archival documents for use by the applicant; Server (2) stored data of the first and simultaneously updates added by continuous processing of new documents; and Server (3) is not accessible from outside through digital network, but stored all digital archive documentation and from here there should be no often exit. In Server 3 only entered document and stored as recent bank. From there, the document will be drawn only if it is missing or damaged document on server 1 and 2.Thus, through this categorization could be provided for long time electronic documents (digital), until to new modern inventions of modern digitalization technology that would ensure the preservation of documents for the 'real' long-term or permanent time.

Key words: long-term storage, digital document, isolated server, digital signature, digital memory

\section{Gestione degli archivi digitali e conservazione a lungo termine dei documenti}

\section{SINTESI}

Come detto sopra, nell'era della tecnologia digitale, la conservazione del materiale archivistico digitale (DAMDigital Archive materiale) è una nuova sfida per gli archivi. Ma anche sta guadagnando cittadinanza, insieme con la grande diffusione di questa tecnologia, non solo nelle istituzioni statali, scientifiche, di produzione, in ogni sfera della vita. Per quanto il singolo individuo si sia dotato di dispositivi digitali estremamente complessi (Smartphone) con grande accesso a comunicazione remota con video e audio, accesso a internet, la messaggisti$\mathrm{ca}$, materiali video e molte altre opportunità, di utilizzare le informazioni rilevanti per le esigenze e gli interessi degli utenti. Questo DAM prodotto è di pari importanza al materiale d'archivio classico, e deve essere mantenuto e conservato professionalmente in Archivio di Stato alle migliori condizioni tecniche e tecnologiche. Problema pressante e molto importante è la conservazione dei documenti digitali nella loro forma originale. Essere conservato e dotato di elementi di sicurezza aggiuntivi nonché la proprietà degli archivi, attraverso emblemi, sigilli ed altri elementi di sicurezza che vengono aggiunti al documento in alcune parti, che non ne impediscono una lettura chiara. La cosa importante è l'uso del documento digitale nei contenziosi, come la prova originale che dà reale cittadinanza ai documenti, in maniera indiscutibile e di facile accesso, e aggiungendo al documento collegamenti a pagine web, per verificarne l'autenticità. Dove esistano problemi di bilancio, non dobbiamo sottovalutare la proposta di mantenere una copia del DAM sui server di archivi isolati, che possano garantirne lo spazio all'interno delle aree di stoccaggio. Infine, è importante che gli archivisti formulino chiaramente le loro preoccupazioni, le loro esigenze e necessità, derivanti dall'impatto della tecnologia digitale. La conservazione permanente del DAM sarà effettuata trasferendo dopo un certo tempo il passaggio dai server usati a server più moderni. Tale limite aumenterà nel futuro, perché le nuove invenzioni, imposte da una elevata dinamica di sviluppo ridurranno le dimensioni dei server ed aumenteranno la capacità di memoria. Nuovi programmi infor- 
matici faciliteranno il trasferimento di DAM da vecchi server a quelli nuovi con programmi e più avanzati, in grado di assimilare e accettare i materiali dai computer delle generazioni precedenti. Il futuro appartiene allo sviluppo della tecnologia informatica, e con esso si svilupperà anche l'archivio digitale, in quanto il principio di base della tecnologia informatica è il continuo aumento della capacità di memoria, in proporzione inversa al piccolo volume fisico dei dispositivi digitali ed a meno quantità consumo di energetico. Dove vi è memoria digitale, là vi è un archivio digitale, di qualsiasi forma siano le informazioni ed i documenti depositati.

Parole chiave: conservazione a lungo termine, documenti digitali, server isolati, firma digitale, memoria digitale

Upravljanje elektronskega arhiva in trajna hramba arhivskega gradiva

\section{IZVLEČEK}

Sodobni elektronski arhivi so moderni arhivi, ki s pomočjo velikih računalniških sistemov hranijo originalne arhivske dokumente s pogledom na čas, ko je gradivo ustvarjeno. Vrednotenje arhivskega gradiva v arhivih na Kosovem se izvaja v dveh smereh. Prva smer je ta, da se odbira klasično gradivo (na papirju), ki ima lastnosti arhivskega, za pretvorbo v digitalno obliko, ter druga smer, kjer se odbira gradivo, ki v inštitucijah primarno nastaja na računalnikih in medmrežju. Upravljanje tega digitalnega gradiva zahteva postopke in profesionalne standarde za njegovo hrambo in strokovno obdelavo $s$ strani arhiva, da bi gradivo bilo dostopno raziskovalcem in zainteresiranim uporabnikom. Dostop do digitalnega gradiva bi moral biti hiter in enostaven postopek, ki bi istočasno ščitil gradivo pred vdorom "hekerjev" in oseb slabih namenov. Za dosego tega cilja, digitalni dokument mora zagotoviti celovitost videza izvornega dokumenta. Uporabnik namreč nima možnosti posegati $\mathrm{v}$ dokument ter ga spreminjati, kajti deluje $\mathrm{v}$ zaščitenem okolju, ki ščiti celotno okolje dokumenta v obliki staljenega pečata, ki istočasno kaže lastništvo določenega arhiva. Varnost gradiva in dokumentacijske baze za zunanje uporabnike bo mogoče organizirati z odlaganjem in hrambo na treh nivojih: strežnik (1) bo hranil arhivsko gradivo za uporabo ustvarjalca; strežnik (2) bo shranjeval podatke prvega strežnika in obenem posodobitve, ki se bodo dodajale ob tekoči obdelavi novih dokumentov; in strežnik (3) ne bo dostopen od zunaj preko digitalne mreže, ampak bo hranil vso elektronsko arhivsko gradivo brez odprtega izhoda. Na strežnik 3 se dokument vnaša in shranjuje le kot nedavni vnos. Od tu se bo prenašal le v primeru, da na strežniku 1 ali dve ta dokument manjka oziroma je poškodovan. S tako kategorizacijo, bi se omogočila dolgoročna hramba elektronskega gradiva do izuma moderne digitalne tehnologije, ki bi zagotovila hrambo gradiva za resnično dolgi rok oziroma trajno.

Ključne besede: dolgoročna hramba, digitalni dokument, izoliran strežnik, digitalni podpis, digitalni spomin

\section{Archive and digitization}

With the birth and development of information technology, use of computers in offices and institutions, private life and the preservation of digital documents, the possibility of scanning and sending of this material among Internet has produced a new reality for the work of the archives. This reality and this new technology have born digital archives. "A digital archives are a repository that stores one or more collections of digital information objects with the intention of providing long-term access to the information. Digital archives can be a sophisticated, multi-tiered storage system or simply

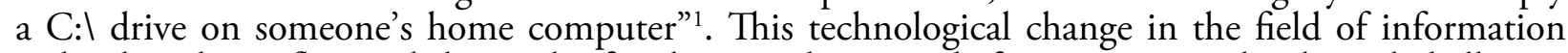
technology has influenced the work of archives and putting before pressing technological challenges with documentation produced on the basis of this technology. Obligations arising in a front of the archives in general are different and immediate; that existing archive material and that formed in the digital way in the computer and Internet age, how to organize, classify, preserve and to serve users through information technology, without losing and risk the identity and validity of documents. This requires that the archive be done in three ways.

\section{Digitalization of classic archive materials}

To make the accessible to users existing archive subject, compatible with existing information technology (IT) from computer and Internet era, need to become digitization of classics documents (written paper) for more needs of practical using. "Documentation through pepper is still much pres-

1. Digital Archives, November 8th, 2005, No Comments, Digital Preservation, Terms \& Definitions, http://archivemati. ca/2005/11/08/digital-archives/ 20.05.2015. 
ent at the creation, processing and exchange of information. Because of its large volume, this type of documentation each time become more difficult to have access at it and occupies large space" (Aliu, 2006, p. 547). Digitalization process has made possible modern technology as the invention of the scanner and software, for storing scanned material with the original picture (view). "Electronic archive, for now, represents the most modern method of archiving the documents. The method is based on the use of the scanner, which document (photo) followed in electronic form on the computer where the documents pictures is stored" (Aliu, 2006, p. 549). This of course takes time and resources but is a necessity, imposed by the era of computer and digitizing all vital services, in this way and the need for the use of archival documentation.

\section{Digitalization of microfilmed archive materials}

From the early of technical electronic tools existed microfilming techniques as a new technique of preserving the archive material in smaller spaces volume and easily accessible. Exactly the time of high development computer information technology has become indispensable and conversion of microfilm archive material to be transformed into digital materials, without that someone may have nostalgia for this technique. "Mixt archiving represents a technical-technology process protecting archival information through a combined method of microfilming and digitization. It implies the acceptance and implementation of all the good qualities of microfilm with used all the benefits of digitization. It is a reliable and economically based form to protect archive materials and other written cultural heritage" (Shabotiq, 2011, p. 114). Certainly computer programs through liaison elements and the passage of information from microfilm apparatus pass into computer data, have enabled this action, facilitating the transformation process and time.

"For this interface between the computer and microfilm had developed micrograph equipment, and equipment for hybrid systems, which also includes output computer means and tools for computer access, as well as their combinations" (Aliu 2005, pp. 391-392). Despite the existing volume of microfilmed archive, it as a process and procedure of transformation in the form of digitized documents must pass technically, to be compatible with the technology of the time and manner of use.

\section{Disposition and preservation of archive material produced in the era of comput- ers}

With the installation of personal computers as a tool to work in state administration, public and private institutions, the production of digital archive has become a reality and had to provide solutions for classifying, storing and managing it. "Today, the holder of documents is not by any means a paper, but an electronic carrier, with condition that responds to the character and credibility provided by law. Therefore, to raise sensibility about the importance of preservation of documents, professionals have approached the new methods, as that is electronic archiving of documents" (Ismaili, 2011, p. 87). However it is important to define and have an official instruction with basic criteria, of what can and should be evaluated as a digital document that formally submitted with relevant procedure in the respective archive. "Electronic document for archiving submitted in a standard format in information holder or submitted online in archive responsible sector. After successful submission, the documents subjected to segregation or transferred to the place of delivery or thou shalt be a hallmark, to exclude a subsequent intervention to the same effect" (Osmani, 2003, p. 13) completed work, because this material should be processed.

\section{Acceptance and disposition of digital archive material (DAM)}

By taking digital documentation starts the change of working practice in the archives, by way of classifying and its processing on former classical paper, new technology requires new approaches and methods in the work process. "For this purpose appear needs to use modern information and communication technologies. So "classic paper" as information carriers of different documents - as folders, documents etc. - will be replaced by electronic counterparts. But since the latter are not simply electronics copying of their predecessors on paper, but have their own special characteristics, it will change to a considerable measure organizational performance - from receipt by mail to archiving" (Rumschöttel, 2001, pp. 34-35). 
Within the working on $\mathrm{ADM}$ is important processing plan and a clear definition of what is of interest, should be described clearly the procedures and methods of work with this new type of documentation. "In order that electronic documents estimate to become more functional and enforcement, it is necessary to be prepared in advance classification plan. Classification of electronic documents is one of the most important tasks and more complicated. This classification should be clear and understandable" (Osmani, 2009, p. 25). With greater development and massive use of information technology, ADM produced wholesale and storage capacity begins to overflow its manufacturers, because there are limits of the memory capacity, to store continuously documents on an office computer. Therefore, legal and professional regulations above archive management should be supplemented in accordance with the new influx of MAD. "Assessments of documents generated in the electronic media, in this direction are not brought yet any guidance. Archives State Agency of Kosovo is working that protection of electronic documents to regulate by specific legal provisions, or incorporate them into Law on Archive Material and Archives" (Ibid., p. 28). Is n't enough only to change and fill up amendments and regulatory documents, but this issue requires technical care in the field of IT that digital documents, to be processed and technically easy to use by interested users. "It is in the interest of enforcement that the information obtained by applying IT, in the case Software - Updates, or reorganization, can return to other systems or to go from the old application to a newer (migration). At the time of delivery to the archive, the documents must be readable on computers that are circulating on the market" (Sinani, 2001, p. 44). It is understandable that this supplement of regulations provides requires to foreseen the development of information technology for many years ahead, that innovation in IT not exceed the legal regulations and technological capacity to manage the MAD within a short time.

\section{Storage long-term digital archive materials}

Production and availability of digital documents is reality and like important documents on time is estimated to be stored in the archive. The first challenge is how to maintain this document in its original form, that tomorrow to serve as a scientific source or authentic evidentiary document with legal power and on legal contexts. "On electronic form of documents in principle is possible to manipulate not only at look like original, as well as the source. For this reason the classic document of public confidence in the electronic circuit is not possible to use for the testimony of the reliability the content of electronic document content" (Novak, 2008, p. 84). Digital documents in comparison with classical documents lose some elements that had to be the only original document, for example, not its variability since the act of creation.

"However, enumerated writing technology has provided some opportunities for them somehow regain lost these qualities, among which the most important are:

- Salvation of the first version and its entitlement as such with the necessary commentary;

- Acceptance of choice for automatic reporting of any adaptation of the text;

- Automatic difference of meta-text from new text, that added;

- Limit the opening and the intervention in the text with the secret password;

- Reservation of opening only for reading text;

- Maintain separate default as single of every revised version of the text” (Sinani, 2001, p. 73). Is obviously that Information technology has offered many advantages for processing and compensation of some elements of the classic document and on digital documents, which opens perspective for more advanced forms of enrichment of digital documents that can be approximated in the future the similarity of virtual reproduction of the classic original documents.

\section{Access to the digital documents}

The purpose of archiving all types of documents, as well and archiving of digital documents, made to serve the interested users. But at the digital documents alters the way of access, the user it done remotely and via the Internet. Processed documents and determined to use, should be created technological conditions for them to be seen and used by interested parties. "Since the authenticity and ownership of the digital documents can't be determined without problems, such in the case of paper documents, along with the classic archiving rules documents should take into account and some other 
rules, such as protocol of action, control various options of the same document as well as maintenance on the computer without the possibility of change and manipulation" (Osmani, 2003, p. 15). The right to access documents remotely through the internet gives the ability for bad intention people who want to harm the documents, therefore requires that this issue to be regulated in such a way, that user can only use and served with the documents, but without opportunity to damage him in identity and originality.

\section{Identity and immutability of digital documents}

Digital documents can be submitted to various programs, because there come those visuals, documents written in word, pictures in the jpg program, but it also includes video material, audio etc. In the form that usually archive keeps, is forms that document is transformed into pdf program, as the first measure to not interfere with the changes in to the document and it to preserve the original appearance of the foundation. Therefore the same thing happen with the preservation of photos, audio and visual materials, acted in the procedure that they are stored in computer programs that retain the original identity and do not allow changes. "Authenticity The digital material is what it purports to be. In the case of electronic records, it refers to the trustworthiness of the electronic record as a record. In the case of "born digital" and digitized materials, it refers to the fact that whatever is being cited is the same as it was when it was first created unless the accompanying metadata indicates any changes. Confidence in the authenticity of digital materials over time is particularly crucial owing to the ease with which alterations can be made"2. Just to try to preserve the identity of the document, appear the need for intervention in the processing and adaptation of the original document of the creation form, preparation for external use by interested user. This transformation process requires a standard program that is defined by archive for example in PDF which enables to maintain the same appearance of the original document, but absolutely must be added in the ordered corner the emblem of the archive, seals and archive security element of the digital document for non-variability. "Digital Preservation Refers to the series of managed activities necessary to ensure continued access to digital materials for as long as necessary. Digital preservation is defined very broadly for the purposes of this study and refers to all of the actions required to maintain access to digital materials beyond the limits of media failure or technological change. Those materials may be records created during the day-to-day business of an organization; "born-digital" materials created for a specific purpose (e.g. teaching resources); or the products of digitization projects. This handbook specifically excludes the potential use of digital technology to preserve the original artifacts through digitization. See also Digitization definition below" ${ }^{\text {. }}$ This assurance is enough for storing and ensuring interference by internet perpetrators in the form of the original document that is available to users. But all these measures do not prevent the user that after discharges or copy the document to not interfere in it. On the other hand it is known that the digital archive document mission is to prove a fact the original and undisputed for an issue. Final proof of digital archival document is when he earns the right to officially used in judicial expertise. This scale can be achieved when the mentioned document elements except security, authenticity and relevance, should be incorporated in a visible track data (link) of the web page source, the same as quoting from the Internet, because the interested party can verify at the moment through clicks on the Internet at the given address. When it resulting that copies are identical to the original from website clicking on the archive, only after that document has completed his full mission of digitization and the Internet era. Also an issue of authenticity of digital document on daily activities is also increasing its reliability through electronic signature, as a form of digitized signature by hand. "An electronic signature is any electronic substitute for the traditional handwritten signature. A frequently used technique in many electronic document management systems for creating electronic signatures is the "digitized handwritten signature" (Boudrez et al, 2005, p. 18). This digital signature option is also a success more, which open new opportunities for the reliability of digital documents, which opened opportunities for versatile use at the time of the Internet and digitalization.

2. Digital Preservation Coalition, Digital preservation handbook, http://www.dpconline.org/advice/preservationhandbook/introduction/definitions-and-concepts.

3. Digital Preservation Coalition, Digital preservation handbook, http://www.dpconline.org/advice/preservationhandbook/introduction/definitions-and-concepts. 


\section{Forms of organization the digital archives}

The form of organization of digital archives must be functional and safe, based on the level of information technology that is in use. Usually the organization of archives is based on logical organization of movement road of archival document, from the creator up to user. The best form of this organization is received for model and is called The Open Archival Information System -OAIS. "The Open Archival Information System (OAIS) model (ISO standard 14721) is a high-level reference model that is being used by organizations world-wide to build further understanding, consensus, and interoperability for organizations that are implementing digital archives to address digital preservation issues" ${ }^{\prime}$. This system developed by the Cornell University Library from USA, can be better understood from the present scheme.

\section{The Open Archival Information System (OAIS) Reference Model}

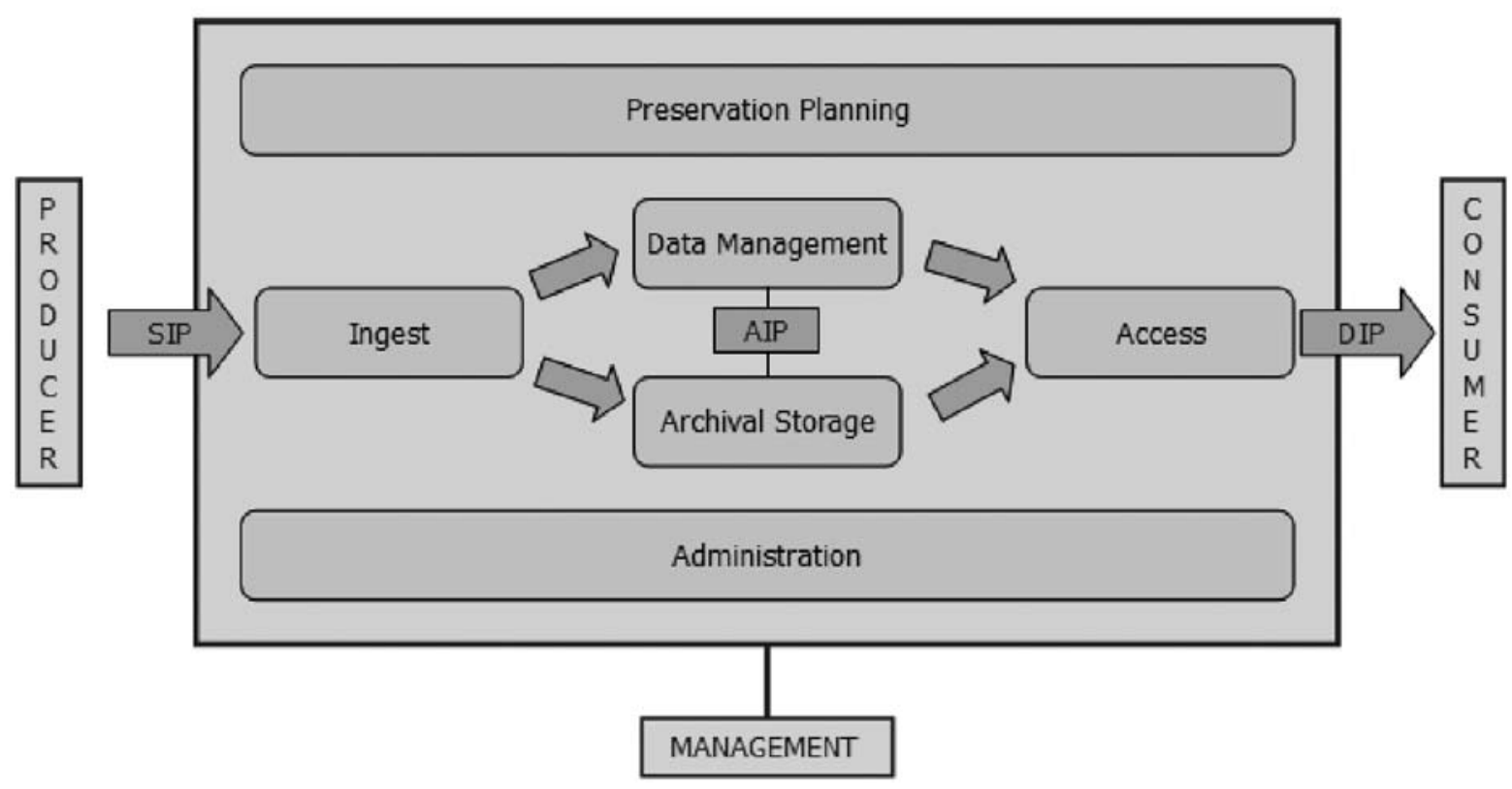

Below we present a description and explanation of the scheme. "The OAIS recognizes three primary types of information packages: 1). The Submission Information Package (SIP), is the version of the information package that is transferred from the Producer to the digital archives when information is 'ingested'. 2). The Archival Information Package (AIP) is the version of the information package that is stored and preserved by the digital archives. The AIP consists of the information that is the focus of preservation, accompanied by a complete set of metadata sufficient to support the digital archives' preservation and access services. 3). The Dissemination Information Package (DIP) is the version of the information package delivered to the Consumer in response to an access request"s. What made safer ADM storage by internet bad makers and non-damage it through outside intervention, in terms of organization of the archive should be in space scheme named as "Archival Storage", should be added an additional independent space which should be appointed "Isolated Archival Storage".

4. Digital Archives, November 8th, 2005, No Comments, Digital Preservation, Terms \& Definitions, /http://archivemati.ca/2005/11/08/digital-archives/ 20.05.2015.

5. Digital Archives, November 8th, 2005, No Comments, Digital Preservation, Terms \& Definitions, /http://archivemati.ca/2005/11/08/digital-archives/ 20.05.2015. 


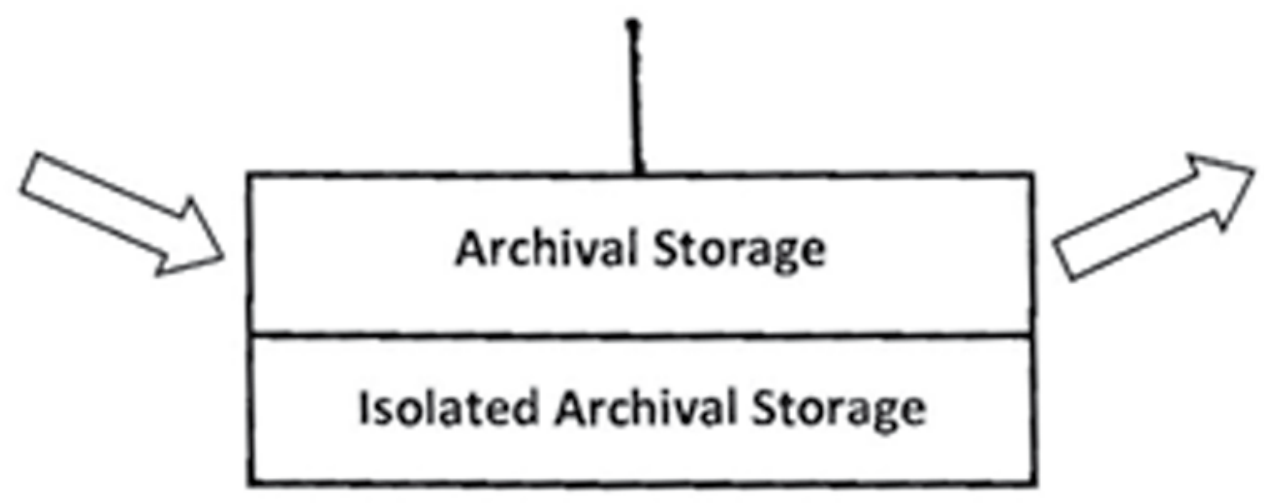

Isolated Achival Storage

This storage, more exactly its server will not have access or connection with any types of Internet access. In this warehouse transfer of documents will be submitted with physical hard disk, external hard disk or similar tools. This repository serves to preserve the original of the original DAM. There document deals only one time, when is damaged his copy and asked to fill in the server access (Access) of users. This warehouse has been appointed as the server III (three). Ranking of servers will look like this: (Archival Storage) server 1, (Access) - server 2, and (Isolated Archival Storage) - server 3. In this 'isolated storage' will be preserved and documents classified as secret documents, until when a legal deadline expires, to be published for interested users. Remains that, the server 3 is a measure to ensure that original document will be untouched, from which can be reproduced damaged copies during using or other factors.

\section{Long-term/permanent preservation of digital documents}

With the current level that is thought information technology, exist the idea, DAM cannot be stored for long time and must be renewed after a decade that it is not destroyed. "According to data announced by computer specialists, computer printings can be self-preserve no more than a few tens of years. It is recommended that enumerated electronic typewritten, maximum within 10-15 years, be transferred to a next memory, in other archives, not to become dead writings and finally unreadable, because the ignorance of the old program from the newest programs (Sinani, 2002, p. 443). For the present moment is understandable that copying and recopying of the DAM is the only way of preserving for the longer term, but exist the authors who have in mind the cost of this process regardless it is necessary. "Another alternative for insurance of readable electronic information through time is a regular copy. However, when the scope of information in electronic form grows, it will probably become a huge financial burden" (Dollar, 1999, p. 70). Limited timeframe of 10 to 15 years of DAM conservation is real concern for archivists and archive scientists. If the DAM deposited in "Archival Isolated storage - server 3", as illustrated above, as a precondition of physical preservation and the impossibility of any kind digital contact from unauthorized persons, transfer at the appointed time on other servers to renew the duration of sustainability IT on the time will find new solutions. With the current dynamic of IT development has done the occupation of institutions, families and individuals, discovering small computer for the volume but with great skill digital memory such as smart phones, very soon will discovered the servers with longer duration, great physical smaller volume and with exceptional memory capacity. Also we are witness of time, the new computer programs always leave open possibility for acceptance and assimilation of material produced and processed by older software versions and older generations of computers. 


\section{Reference list}

Aliu, Bekim (2005). Pajimet për daljen dhe hyrjen e të dhënave dhe informatave kompjuterike në mikrofilm, Vjetari, Nr. 33-34.

Aliu, Bekim (2006). Menaxhimi elektronik bashkëkohor. Vjetari, Nr. XXXV - XXXVI, Prishtinë.

Dollar, M. Charles (1999). Arhivistika i Informacijske Tehnologije. Utjecaj informacijske tehnologije na arhivsku teoriju i praksu. Zagreb: Hrvatski Državni Arhuiv.

Ismaili, Ismail (2011). Rëndësia e Arkivave Elektronike. Vjetari Nr. 45-46.

Novak, Miroslav (2008). Problemet arkivore më të rëndësishme të arkivimit të formave. Vjetari, Nr. 39-40.

Osmani, Jusuf (2003). Roli i arkivistit në krijimin, mbrojtjen dhe ruajtjen e dokumenteve elektronike. Vjetari, Nr. 29-30.

Osmani, Jusuf (2009). Ekspertiza e vlerësimit të dokumenteve elektronike në organizata dhe në arkiv. Vjetari, Nr. 41-42.

Rumschöttel, Hermann (2001). Drejtor i Përgjithshëm i Arkivave të Bajernit, "Dokumentet Numerikë “, Dokumenti i Numerizuar (Sinteza dhe përvoja evropiane), Tiranë, 2001.

Shabotiq, Izet (2011). Përparësitë e mbrojtjes së lëndës arkivore digjitale. Vjetari Nr. 45-46.

Sinani, Shaban (2002). Jetëgjatësia e dokumentit të numerizuar dhe disa probleme të besueshmërisë së tij. Vjetari, Nr. XXVII-XXVIII.

Sinani, Shaban (2001). Jetëgjatësia e dokumentit të numerizuar dhe disa probleme të besueshmërisë së tij. Arkivi Shqiptar, Nr. 2, 2001.

\section{Internet sources}

Boudrez, Filip, Dekeyser, Hannelore, Dumortier, Jos (2005). Digital archiving. Available at http://www.expertisecentrumdavid.be/docs/digitalarchiving_manual.pdf.

Digital Archives, November 8th, 2005, No Comments, Digital Preservation, Terms \& Definitions. Available at: http://archivemati.ca/2005/11/08/digital-archives.

Digital Preservation Coalition, Digital preservation handbook, Available at: http://www.dpconline.org/advice/ preservationhandbook/introduction/definitions-and-concepts

http://www.dpconline.org/advice/preservationhandbook/introduction/definitions-and-concepts

http://www.dpconline.org/advice/preservationhandbook/introduction/definitions-and-concepts

\section{SUMMARY}

As noted above that in the era of IT, maintenance of DAM (Digital Archive Material) is a new challenge for archives. But it also is gaining citizenship, along with the large spread of this technology, not only in state institutions, scientific, manufacturing, but in every sphere of life. As much as the individual himself is equipped with highly complex digital device (Smartphone) with great access of remote communication with video and audio, internet access, messaging, video materials and many other opportunities, to use relevant information for needs and interests of users. This DAM produced is of equal importance as the classic archive material, and needs to be maintained and preserved in state professional archives with maximum technical and technological conditions. Pressing issues and very important is the preservation of digital documents in their original form. Be preserved and equipped with additional security elements and ownership of the archives, through emblems, seals and other security elements that are added to the document in certain parts, which do not prevent his appearance and clear reading. The important thing is the use of digital document in litigation, as the original evidence, which gives real citizenship of documents, the undisputed, easily accessible, and adding on the space of the document extending link of web page, order to verify the authenticity of that document. Where are budget options, we should not underestimate the proposal for maintaining a copy of the DAM, on the servers of isolated archives, that can ensure the place within the archive storage areas. Finally it is important that archivists to formulate clearly their concerns, their needs and requirements, arising from the impact of IT, and their resolution will make scientists and IT programmers, much more easily than it can imagine. Permanent preservation of DAM will be by transferring after certain periods of actual servers in most modern servers. This time limit will increase in the future, because new inventions, imposed by high dynamics of development of IT, which will reduce the size of the servers, will increase memory capacity and extended more life expectancy. Through new 
Fikrie BERISHA: Digital Archives Management and Permanent Storage of Documents, 153-161

computer programs will facilitate the transfer of DAM from old servers to the new servers and even with new programs and more advanced, able to assimilate and accept the materials from the computers of previous generations. The future belongs to IT development, and with it will develop digital archive, because the basic principle of information technology is the continuous increase in of memory capacity, in inverse proportion with the small physical volume of digital devices as well as less quantity energy use. Where is digital memory, there is a digital archive, of any form of information and documents deposited.

Typology: 1.04 Professional Article

Submitting date: 14.03 .2015

Acceptance date: 09.04.2015 
